\title{
Mechanism of the Initial Events in the Sorption of Marine Bacteria to Surfaces
}

\author{
By K. C. MARSHALL*, RUBY STOUT AND R MITCHELL \\ Laboratory of Applied Microbiology, Division of Engineering and Applied Physics \\ Harvard University, Cambridge, Massachusetts, U.S.A.
}

(Accepted for publication 3 August 197I)

SUMMAR Y

The sorption of two marine bacteria to surfaces involved an instantaneous reversible phase, and a time-dependent irreversible phase. Reversible sorption of the non-motile Achromobacter strain R 8 decreased to zero as the electrolyte concentration decreased, or as the thickness of the electrical double-layer increased. The electrolyte concentration at which all bacteria were repelled from the glass surface depended on the valency of the cation. The reversible phase is interpreted in terms of the balance between the electrical double-layer repulsion energies at different electrolyte concentrations and the van der Waals attractive energies. Even at the electrolyte concentration of seawater, the bacteria probably are held at a small distance from the glass surface by a repulsion barrier. Reversible sorption often led to rotational motion of the motile Pseudomonas sp. strain R 3 at a liquid-glass interface.

Pseudomonas R 3 produced polymeric fibrils in artificial seawater; these may be concerned in the irreversible sorption of the bacteria to surfaces. Sorption and polymer production were stimulated by $7 \mathrm{mg}$./1. glucose but higher levels inhibited irreversible sorption. Omission of $\mathrm{Ca}^{2+}$ and $\mathrm{Mg}^{2+}$ from the artificial seawater prevented growth, polymer production, and sorption to surfaces by Pseudomonas R3.

\section{INTRODUCTION}

The sorption of bacteria to surfaces is a general phenomenon encountered in natural environments with important ecological implications (Wood, I967; Marshall, 197I). Primary microbial film formation on surfaces immersed in seawater is considered by some investigators to be a prerequisite to fouling by larger organisms such as barnacles (Wood, 1967). The mechanism whereby marine bacteria sorb to surfaces has received scant attention. ZoBell (I943) suggested that, once bacteria are attracted to a surface, firm attachment requires incubation for several hours. He attributed this delay to the need for the synthesis of extracellular adhesive materials. Recently, Corpe (I970 a) has reported the production of an extracellular acid polysaccharide by a primary film-forming bacterium, Pseudomonas atlantica. Glass slides coated with this polymer became fouled with micro-organisms more rapidly than uncoated slides. Corpe (1970 b) has reviewed the literature on attachment of bacteria to surfaces immersed in marine environments.

The present investigation combines a study of some of the colloidal and biological properties of pure cultures of marine bacteria to obtain information on processes involved in the sorption to surfaces.

\footnotetext{
* Permanent address: Department of Agricultural Science, University of Tasmania, Hobart, Tasmania, Australia.
} 


\section{Definition of phases of sorption}

Our studies have confirmed ZoBell's ( 1943 ) suggestion that sorption consists of two phases. The bacteria were first attracted to a surface, and, after several hours, some became firmly attached. These phases are defined as follows.

Reversible sorption is an essentially instantaneous attraction of bacteria to a surface. Such bacteria are held weakly near the surface; they still exhibit Brownian motion and are readily removed by washing the surface with $2.5 \% \mathrm{NaCl}$.

Irreversible sorption involves the firm adhesion of bacteria to the surface; they no longer exhibit Brownian motion and are not removed by washing with $2.5 \% \mathrm{NaCl}$.

\section{METHODS}

Organisms. The bacteria used in this investigation were a motile Pseudomonas sp. strain R 3 and a non-motile Achromobacter sp. strain R 8. Both organisms were isolated from a glass coverslip that had been immersed in natural seawater for $\mathrm{I}$ h., rinsed several times in sterile $2.5 \% \mathrm{NaCl}$, plated by smearing the coverslip on an artificial seawater agar, and incubated $24 \mathrm{~h}$. at $25^{\circ}$. Pseudomonas $\mathrm{R} 3$ required $2.5 \% \mathrm{NaCl}$ in the medium, while Achromobacter $\mathrm{R} 8$ grew equally well in both high and low salt media. Logarithmic and stationary phase cultures of Pseudomonas R 3 refer to cultures incubated for 4 and 24 h., respectively.

Studies of reversible sorption. The behaviour of the motile Pseudomonas $\mathrm{R} 3$ at liquid-glass interfaces was examined by preparing films (Kodak 4 -X reversal film type 7277 ) of the bacteria viewed at the plane of a coverslip by phase-contrast microscopy. Detailed examination of these films made possible a reasonable interpretation of the curious gyratory motions observed with motile bacteria at such interfaces. The maximum velocity of Pseudomonas R 3 was determined by the motility tracking method of Vaituzis \& Doetsch ( I 969).

The effect of electrolyte concentration on reversible sorption was investigated using Achromobacter $\mathrm{R} 8$. This non-motile organism grew in low salt media and very low electrolyte concentrations did not cause lysis. Achromobacter $\mathrm{R} 8$ was grown on nutrient agar (Difco) at $25^{\circ}$ for $24 \mathrm{~h}$. After washing twice in distilled water, portions of the suspension were mixed with equal volumes of a range of concentrations of $\mathrm{NaCl}$ or $\mathrm{MgSO}_{4}$. Drops of these suspensions were run under coverslips supported above slides by broken coverslip pieces. The preparations were stood $30 \mathrm{~min}$. to allow those organisms not sorbed at the liquid-glass interface to fall from view by gravity, so that these cells attracted to the coverslip surface could be counted. The same technique was employed to investigate the effect of divalent cations on the reversible sorption of Pseudomonas R 3 .

Studies of irreversible sorption. Glass slides were cleaned in chromic acid, rinsed in distilled water, and then supported in slots in a sheet of foam polystyrene over an evaporating basin ( I 1. capacity) containing an appropriate medium inoculated with Pseudomonas R 3 . Duplicate slides were removed at intervals, rinsed thoroughly with $2.5 \% \mathrm{NaCl}$, and the previously immersed area of the slide covered with a coverslip. Organisms firmly sorbed (not exhibiting Brownian motion) were counted in at least ten fields on both slides. All counts are expressed as numbers sorbed $/ \mathrm{cm}^{2}$ of glass surface.

The media used included either $2.5 \% \mathrm{NaCl}$ or an artificial seawater (ASW), suggested by T. Waite, which contained (g. l.) : $\mathrm{NH}_{4} \mathrm{Cl}, 0.0007 ; \mathrm{NaCl}, 24 ; \mathrm{KCl}, 0.6 ; \mathrm{MgSO}_{4} \cdot 7 \mathrm{H}_{2} \mathrm{O}, 5$; $\mathrm{MgCl}_{2} .6 \mathrm{H}_{2} \mathrm{O}, 3.6 ; \mathrm{CaCl}_{2}, 0.3 ; \mathrm{NaNO}_{3}, 0 . \mathrm{I} ; \mathrm{KH}_{2} \mathrm{PO}_{4}, 0.0 \mathrm{I} ; \mathrm{FeCl}_{3}, 0.00 \mathrm{I}$; tris- $\mathrm{HCl}, 5.32$; tris Base, $\mathrm{I} \cdot 97 ; \mathrm{P}_{11}$ trace metals (below), Io ml.; $\mathrm{pH} 7 \cdot 8$. The $\mathrm{P}_{11}$ trace metal solution contained (g./1.): di-sodium ethylene-diaminotetracetic acid (EDTA), I; $\mathrm{FeCl}_{3}, 0.0 \mathrm{I} ; \mathrm{H}_{3} \mathrm{BO}_{3}$, 
$0.2 ; \mathrm{MnCl}_{2}, 0.04 ; \mathrm{ZnCl}_{2}, 0.005 ; \mathrm{CoCl}_{2}, 0.001$. Modifications of these media are detailed in the Results section. The concentration of glucose added to artificial seawater is indicated by the number after ASWG, e.g. ASWG-30 indicates $30 \mathrm{mg}$./. glucose.

Pseudomonas R 3 was inoculated on large slopes in $100 \mathrm{ml}$. bottles of nutrient agar (Difco) containing $2.5 \% \mathrm{NaCl}$, and normally incubated $24 \mathrm{~h}$ at $25^{\circ}$. The bacteria were washed once in $2.5 \% \mathrm{NaCl}$ before being inoculated into the test medium to give a final concentration of between $\mathrm{I}$ and $\mathrm{I} 0 \times 10^{7}$ bacteria $/ \mathrm{ml}$.

For electron-microscope studies of irreversibly sorbed bacteria, nickel grids (formvar films) were immersed directly in the medium containing Pseudomonas R 3 ; removed after I h., fixed in $2.5 \%$ formaldehyde in $2.5 \% \mathrm{NaCl}$ (Hodgkiss \& Shewan, I 968) for $30 \mathrm{~min}$., dried, rinsed in distilled water, and dried prior to shadowing with gold-palladium alloy (60\% gold $-40 \%$ palladium).

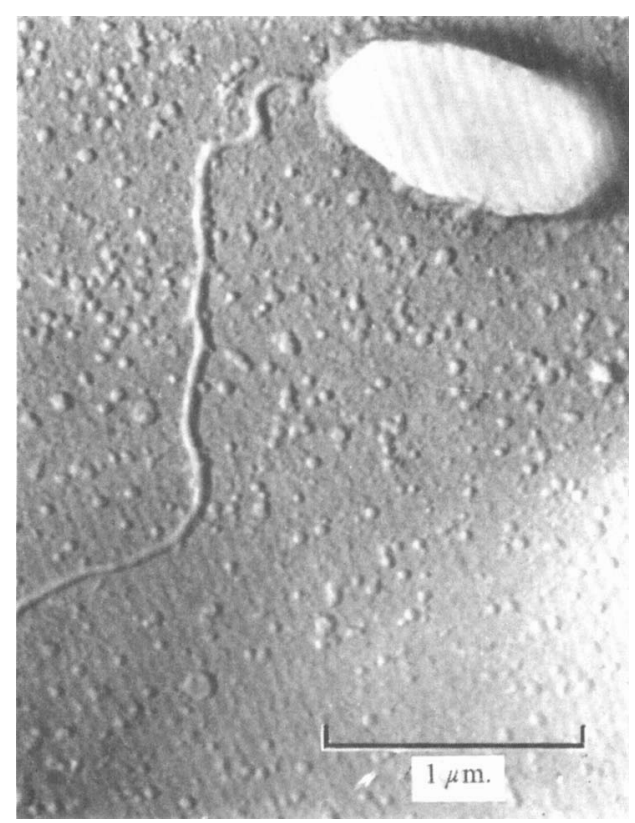

Fig. I. Single polar flagellum of Pseudomonas strain R 3.

\section{RESULTS}

Motility and reversible sorption of Pseudomonas $\mathrm{R} 3$. Pseudomonas $\mathrm{R} 3$ was a motile rod possessing a single polar flagellum (Fig. 1). In common with most motile bacteria, this organism exhibited a peculiar rotational behaviour at a liquid-glass interface. Cine films indicated that such bacteria sorbed at the pole (an edge-to-face association) and, by virtue of the motive force of the flagellum, rotated violently around the fixed pole (Fig. 2). If sorbed in a face-to-face position (Fig. 2), they rotated in either direction in a propeller-like fashion. The bacteria occasionally broke away from the surface and often sorbed at another point. Any non-motile cells were sorbed in a face-to-face position (Fig. 2) and showed only Brownian motion. Both motile and non-motile cells were readily desorbed by washing the glass surfaces in $2.5 \% \mathrm{NaCl}$. 
The kinetic energy of motile Pseudomonas R 3 cells was estimated: the maximum velocity was $33 \mu \mathrm{m}$./sec.; assuming an average mass of $10^{-12} \mathrm{~g}$., then the kinetic energy of a motile organism was $5.45 \times 10^{-18}$ ergs.

Effect of medium composition on irreversible sorption of Pseudomonas R 3 . As reported below, the irreversible sorption of Pseudomonas $\mathrm{R} 3$ was affected by divalent cations in ASW. However, the results in Table I show that deletion of divalent cations from ASW + glucose at $7 \mathrm{mg}$./ . (ASWG-7) did not influence the numbers of bacteria initially attracted to the glass surface.

(a)
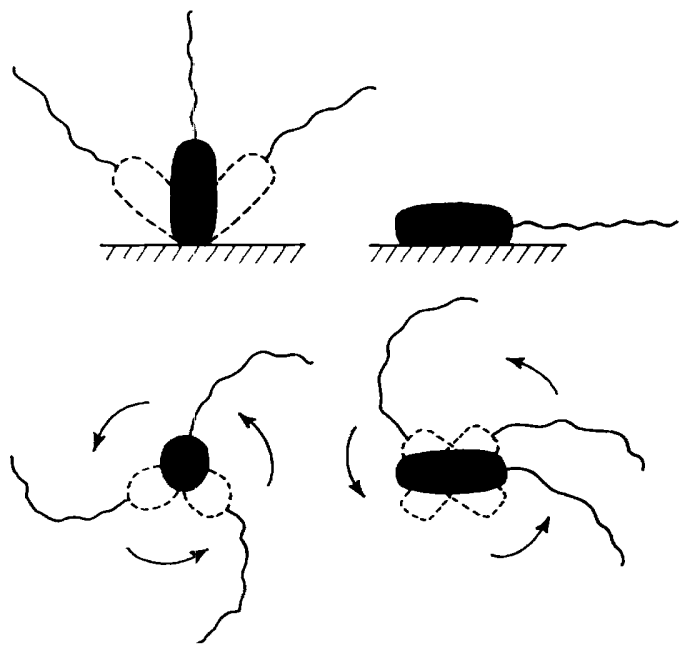

(b)

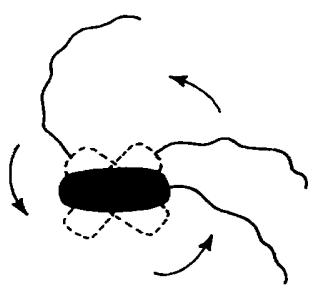

(c)
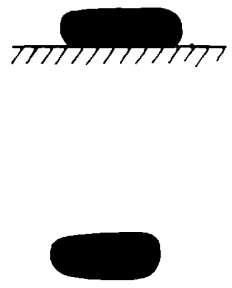

Fig. 2. A diagrammatic interpretation of the reversible sorption of Pseudomonas $\mathrm{R} 3$ to a glass surface: $(a)$ and $(b)$ illustrate the rotational movements of motile bacteria in an edge-to-face and a face-to-face manner, respectively; $(c)$ face-to-face sorption of non-motile bacteria.

Table I. Effect of divalent cations in artificial seawater on the reversible sorption of Pseudomonas $\mathrm{R} 3$

$\begin{array}{lc}\quad \text { Medium } & \text { No. bacteria sorbed } / \mathrm{cm}^{2} \\ \text { ASWG } & 5.35 \times 10^{3} \\ \text { ASWG-Ca } & 5.27 \times 10^{3} \\ \text { ASWG- }-\mathrm{Mg}^{2+} & 5 \cdot 58 \times 10^{3} \\ \text { ASWG-Ca } & 5.42 \times 10^{3}\end{array}$

Effect of electrolyte concentration on reversible sorption of Achromobacter $\mathrm{R} 8$. The number of achromobacteria reversibly sorbed increased with increasing electrolyte concentration or as the thickness of the electrical double layer decreased (Fig. 3). The theoretical thickness of the diffuse double layer $(\mathrm{I} / K)$ was calculated from the expression

$$
K=0.327 \times 10^{8} Z \sqrt{ } c \text {, }
$$

where $Z=$ valency and $c=$ molar concentration of electrolyte. This expression holds for aqueous solutions of symmetrical electrolytes at $25^{\circ}$ (Shaw, 1966).

The bacteria were reversibly sorbed at lower concentrations of a divalent electrolyte $\left(\mathrm{MgSO}_{4}\right)$ than of a monovalent electrolyte $(\mathrm{NaCl})$, an effect clearly related to the greater compression of the double-layer in the divalent system at comparable concentrations. In both electrolyte systems, all the bacteria were repelled from the surface when the value of $1 / K$ exceeded about $200 \AA$. This result suggests that the initial, reversible attraction of bacteria 
to a surface depends on the magnitude of the double-layer repulsion energy at different electrolyte concentrations compared with the van der Waals attraction energy.

Effect of glucose on the irreversible sorption of Pseudomonas R3. Sorption was negligible from $\mathrm{NaCl}$, but appreciable from ASW (Fig. 4). Glucose (7 mg./1.) stimulated sorption from

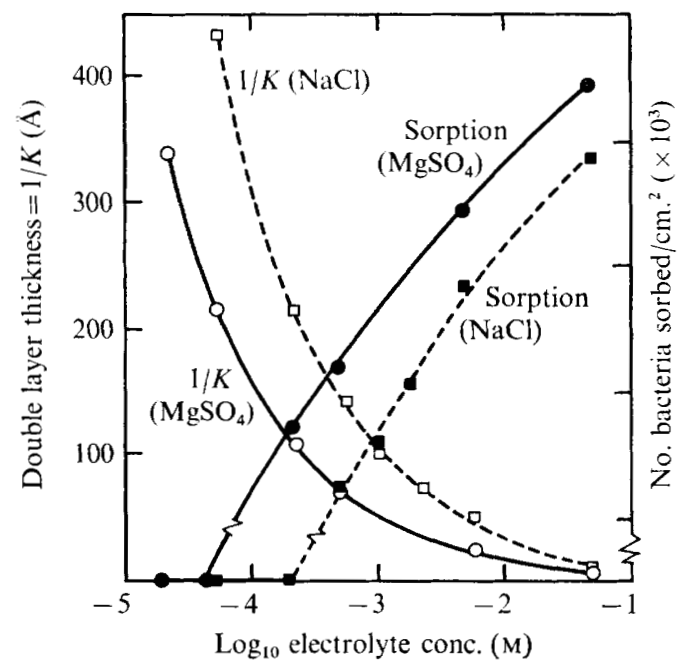

Fig. 3. Reversible sorption of Achromobacter R 8 and the theoretical double-layer thickness (I/K) in relation to electrolyte concentration and valency. $\square-\square, \mathrm{I} / \mathrm{K}$ for $\mathrm{NaCl} ; \mathrm{O}-\mathrm{O}, \mathrm{I} / \mathrm{K}$ for $\mathrm{MgSO}_{4}$; , sorption of Achromobacter $\mathrm{R} 8$ from $\mathrm{NaCl}$; $\mathrm{MgSO}_{4}$. The ionic strength of natural seawater is approximately $0.65 \mathrm{M}$.

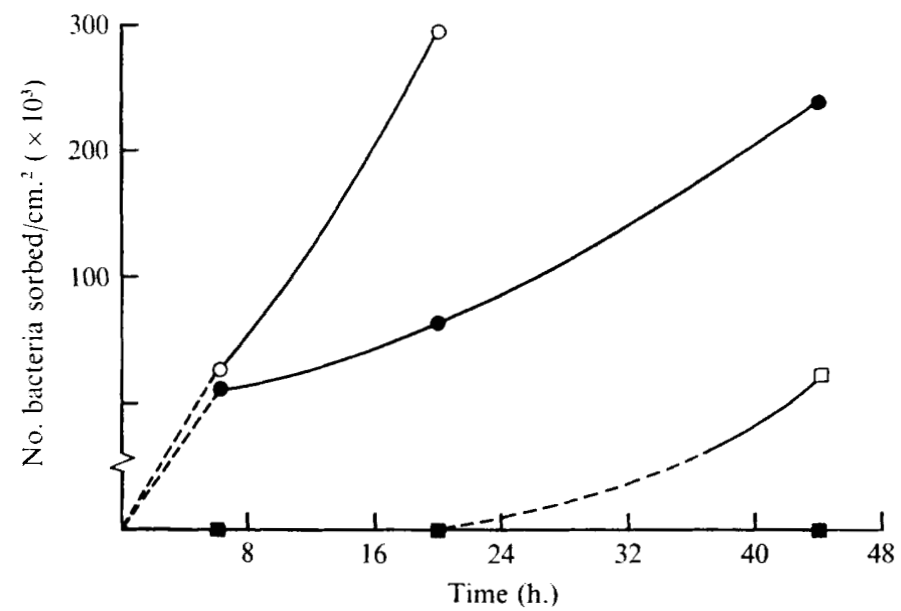

Fig. 4. Irreversible sorption of Pseudomonas $\mathrm{R} 3$ from $\mathrm{NaCl}$ and artificial seawater (ASW). $2.5 \% \mathrm{NaCl} ; \square-\square, 2.5 \% \mathrm{NaCl}+$ glucose $(7 \mathrm{mg}$./1.); $\bigcirc-\mathrm{O}, \mathrm{ASW}+$ glucose $(7 \mathrm{mg} . / \mathrm{l}$ ) ; ASW.

both media. Electron micrographs of grids suspended in ASW or ASWG-7 showed very fine extracellular polymeric fibrils on bacteria sorbed from ASW (Fig. 5); bacteria sorbed from ASWG-7 had many more of such fibrils (Fig. 6).

Although the growth of Pseudomonas R 3 was stimulated by higher levels of glucose 
irreversible sorption of the bacteria from ASWG-30 and ASWG-70 was inhibited completely (Fig. 7). Sorption was rapid from ASWG-7 and moderate from ASW. The irreversible sorption of Pseudomonas R 3 was lowered dramatically even at glucose levels of I4 and $2 \mathrm{I} \mathrm{mg}$. /. (Table 2). Flocculation of bacteria in the bulk suspension was observed in conditions in which sorption was greatest.

Electron micrographs of grids immersed in ASWG-7 revealed large numbers of bacteria all with extracellular polymeric fibrils. Sometimes it appeared that some sorbed bacteria had been sheared from the grid surface by washing, leaving polymer 'footprints' on the grid surface (Fig. 8). Very few bacteria were found on grids from ASWG-I4 and ASWG-2I. Some bacteria showed little evidence of polymer production (Fig. 9), while others appeared to produce abundant polymer (Fig. 10).

Although ASW contained both $\mathrm{NH}_{4} \mathrm{Cl}$ and $\mathrm{NaNO}_{3}$ as nitrogen sources, the individual salts at equivalent nitrogen levels did not influence growth or the irreversible sorption of

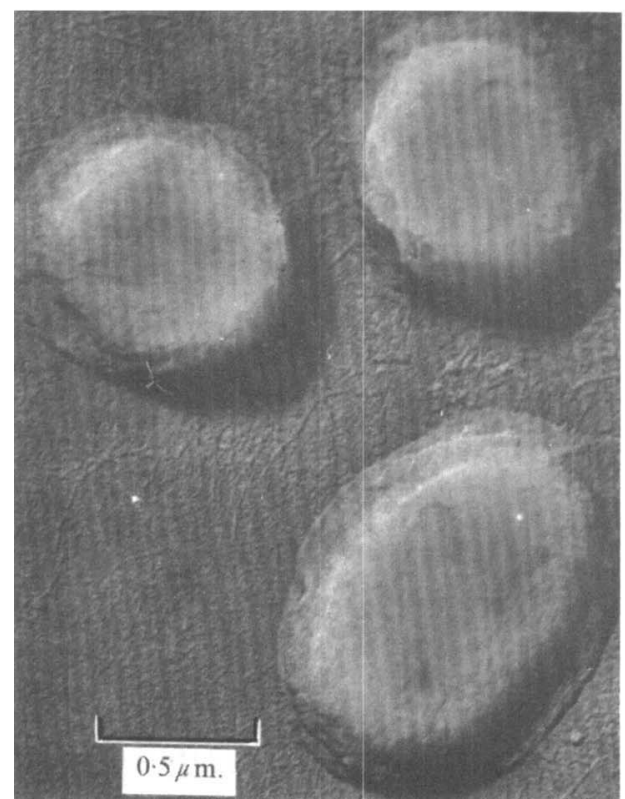

Fig. 5

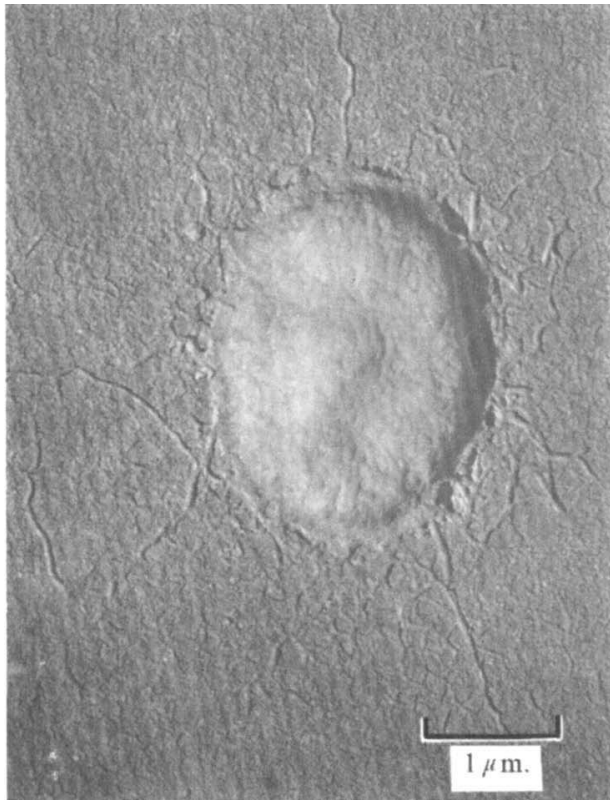

Fig. 6

Fig. 5. Extracellular polymeric fibrils on bacteria sorbed on grid immersed in artificial seawater.

Fig. 6. As in Fig. 5, but grid immersed in artificial seawater + glucose ( $7 \mathrm{mg}$./1.).

Table 2. Effect of glucose levels in artificial seawater on growth and irreversible sorption of Pseudomonas $\mathbf{R} 3$

\begin{tabular}{|c|c|c|c|}
\hline \multirow[b]{2}{*}{ Glucose (mg./1.) } & \multirow{2}{*}{$\begin{array}{c}\text { No. bacteria/ml. } \\
\text { after } 24 \mathrm{~h}^{*}\end{array}$} & \multicolumn{2}{|c|}{ No. bacteria sorbed $/ \mathrm{cm}^{2}\left(\times \mathrm{IO}^{3}\right)$} \\
\hline & & $20 \mathrm{~h}$ & 4 days \\
\hline o & $14.8 \times 10^{7}$ & $44 \cdot 6$ & 488 \\
\hline 7 & $26.1 \times 10^{7}$ & $65 \cdot 8$ & $5 I 4$ \\
\hline 14 & $33.2 \times 10^{7}$ & $2 \cdot 3$ & 78 \\
\hline 21 & $44.1 \times 10^{7}$ & $2 \cdot I$ & $3 I$ \\
\hline
\end{tabular}


Pseudomonas R 3 to glass surfaces. Since all the nitrogen in the basic ASW medium was available to Pseudomonas $\mathrm{R} 3$, then the $\mathrm{C} / \mathrm{N}$ ratios ranged from 0.17 in $\mathrm{ASWG}-7$ to $1 \cdot 70$ in ASWG-70. Consequently, all of these media were carbon deficient, so $N$-limitation was not the reason for production of extracellular polymeric materials in the media.

Effect of divalent cations on irreversible sorption of Pseudomonas $\mathrm{R} 3$. The omission of $\mathrm{Ca}^{2+}$ and $\mathrm{Mg}^{2+}$ (with $\mathrm{Na}_{2} \mathrm{SO}_{4}$ added to provide $\mathrm{SO}_{4}{ }^{2-}$ ) from ASWG-7 prevented the irreversible sorption of Pseudomonas $\mathrm{R} 3$ (Fig. 11). Mere addition of $\mathrm{Ca}^{2+}$ and $\mathrm{Mg}^{2+}$ to $2.5 \% \mathrm{NaCl}+$ glucose did not stimulate the sorption of Pseudomonas $\mathrm{R} 3$ from such a medium. Total numbers of Pseudomonas $\mathrm{R} 3$ in the suspension remained constant in all but ASWG-7, where rapid sorption appeared to be related to the limited growth of the bacteria. Few bacteria adhered to electron microscope grids immersed in ASWG-7 lacking $\mathrm{Ca}^{2+}$ and $\mathrm{Mg}^{2+}$, and those that did showed no evidence of polymer production (Fig. 12).

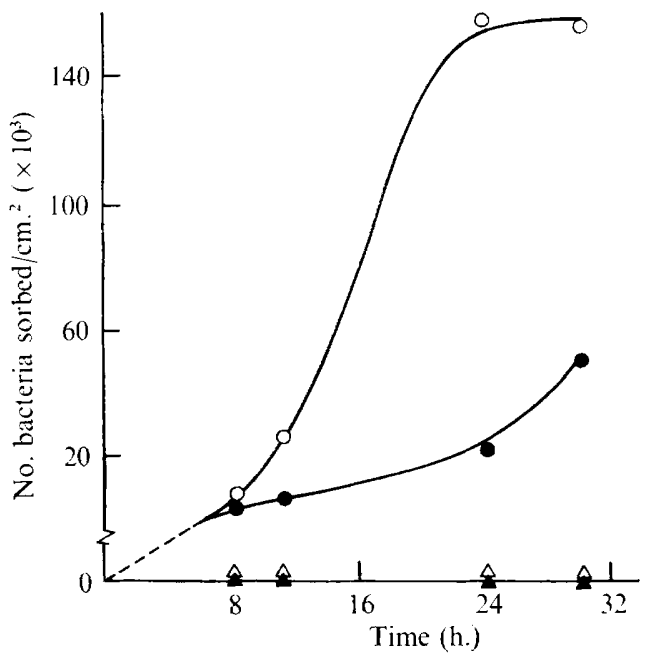

Fig. 7

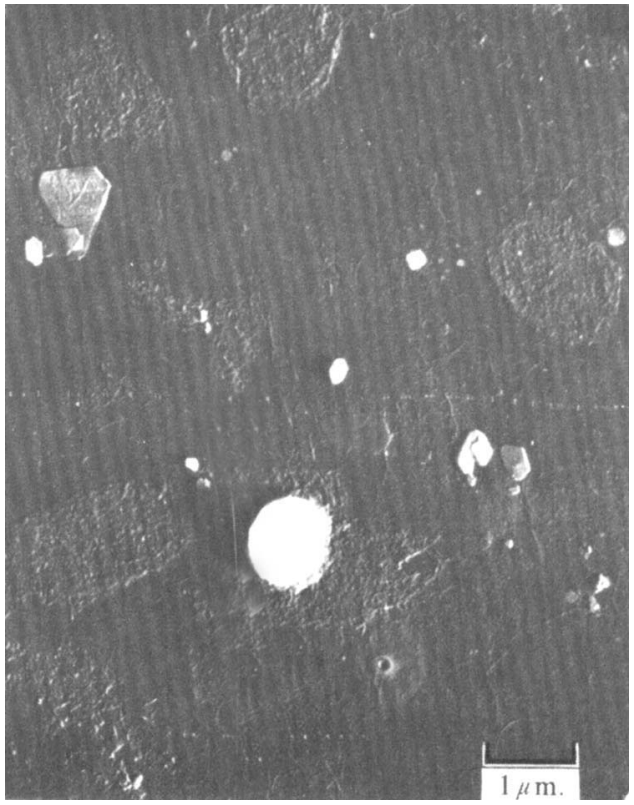

Fig. 8

Fig. 7. Effect of glucose concentration on the irreversible sorption of Pseudomonas R 3 from ASW. - - ASW; $\bigcirc-O$, ASW + glucose (7 mg./l.); $\triangle-\triangle$, ASW + glucose (30 mg./l.); $\Delta-\Delta$, ASW + glucose (70 mg. (l.).

Fig. 8. Polymer 'footprints' remaining after bacteria were sheared from the grid surface.

Table 3. Effect of divalent cations in artificial seawater on the irreversible sorption of Pseudomonas R 3

\begin{tabular}{|c|c|c|}
\hline \multirow[b]{2}{*}{ Medium } & \multicolumn{2}{|c|}{ No. bacteria sorbed $/ \mathrm{cm}^{2}$} \\
\hline & $24 \mathrm{~h}$. & $48 \mathrm{~h}$. \\
\hline ASWG & $242 \times 10^{3 *}$ & $464 \times 10^{3 *}$ \\
\hline ASWG-Ca ${ }^{2+}$ & $155 \times 10^{3}$ & $400 \times 10^{3}$ \\
\hline ASWG-Mg ${ }^{2+}$ & $126 \times 10^{3 *}$ & $280 \times 10^{3 *}$ \\
\hline ASWG-Ca ${ }^{2+},-\mathrm{Mg}^{2+}$ & 0 & 0 \\
\hline
\end{tabular}




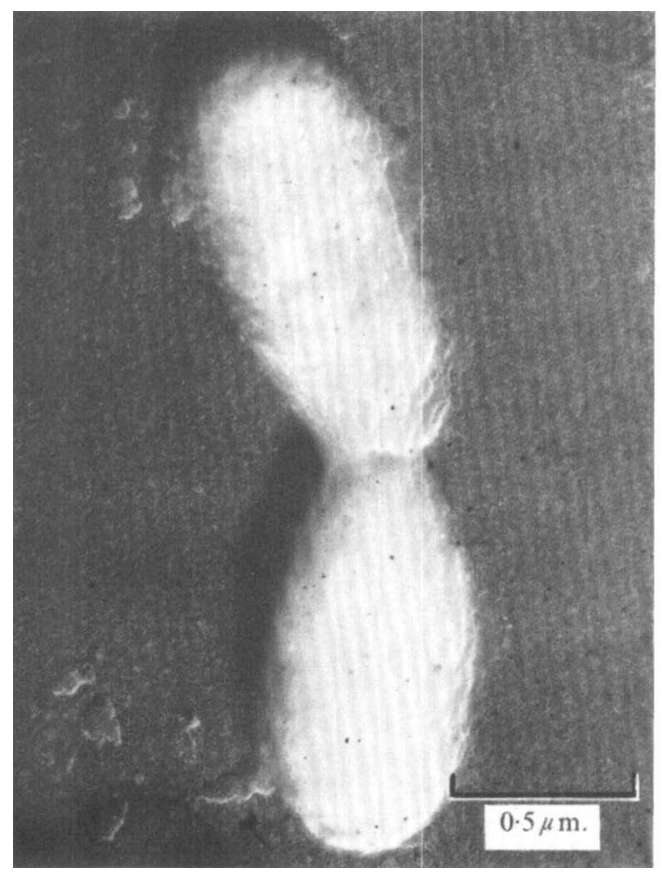

Fig. 9

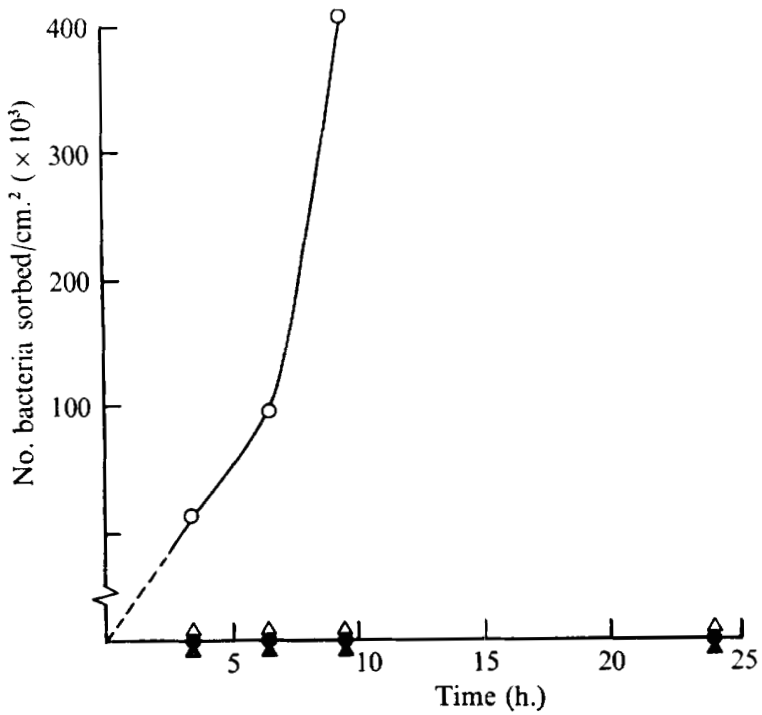

Fig. II

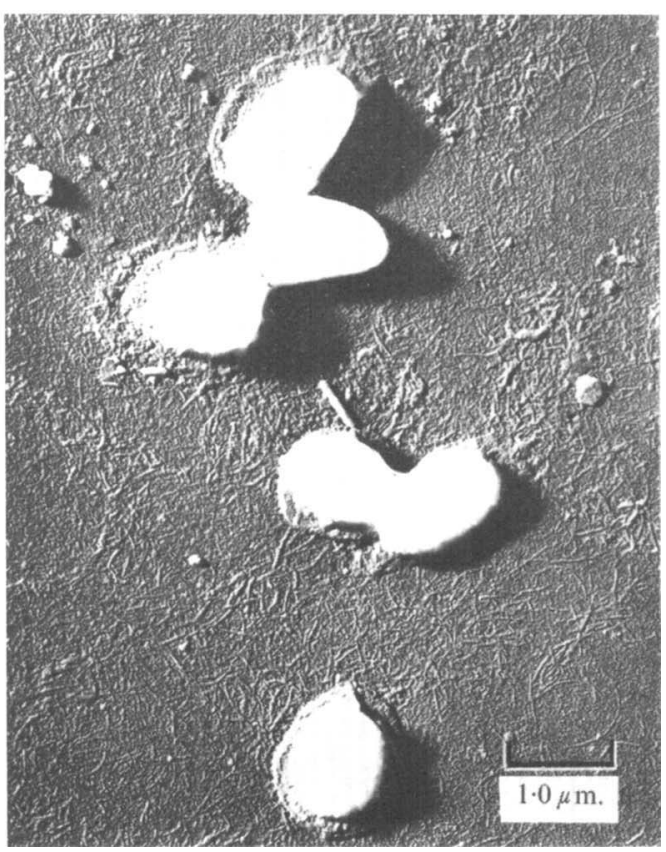

Fig. 10

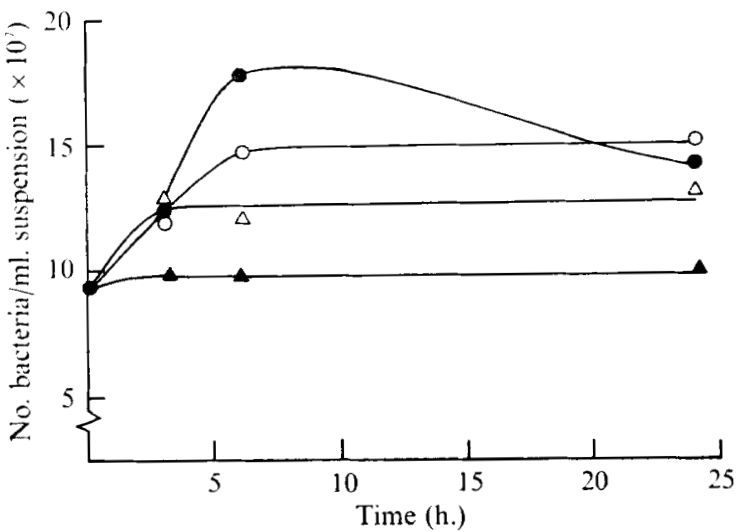

Fig. 12

Fig. 9. Bacterium lacking extracellular polymeric fibrils. From ASWG without $\mathrm{Ca}^{2+}$ and $\mathrm{Mg}^{2+}$.

Fig. I0. Grid immersed in artificial seawater + glucose ( $14 \mathrm{mg}$./1.). Bacterium showing abundant polymer production.

Fig. II. Effect of divalent cations on the irreversible sorption of Pseudomonas $\mathrm{R} 3$ from $\mathrm{NaCl}$ and ASW. $\triangle-\Delta, 2 \cdot 5 \% \mathrm{NaCl}+$ glucose; $\triangle-\triangle, 2 \cdot 5 \% \mathrm{NaCl}+$ glucose $+\mathrm{Ca}^{2+}+\mathrm{Mg}^{2+} ; \mathrm{O}-\mathrm{O}, \mathrm{ASW}+$ glucose; - $-\mathrm{ASW}+$ glucose $-\mathrm{Ca}^{2+},-\mathrm{Mg}^{2+}$.

Fig. 12. Effect of divalent cations on growth of Pseudomonas R 3 in ASWG (glucose at $7 \mathrm{mg}$./1.). $\bullet-\bullet$ ASWG; O-O, ASWG - $\mathrm{Ca}^{2+} ; \triangle-\triangle$, ASWG - $\mathrm{Mg}^{2+} ; \mathbf{\triangle}-\mathbf{\Delta}, \mathrm{ASWG}-\mathrm{Ca}^{2+},-\mathrm{Mg}^{2+}$. 
Although irreversible sorption was inhibited when both $\mathrm{Ca}^{2+}$ and $\mathrm{Mg}^{2+}$ were omitted from ASWG-7, sorption did occur when either was omitted (Table 3). The degree of sorption from the various media (Table 3 ) appeared to be related to the growth of Pseudomonas R 3 in the media (Fig. I2). Flocculation was observed consistently in the ASWG and ASWG-7 without $\mathrm{Mg}^{2+}$, but not in ASWG without $\mathrm{Ca}^{2+}$ or ASWG-7 with neither $\mathrm{Ca}^{2+}$ nor $\mathrm{Mg}^{2+}$. Thus, flocculation in the bulk suspension did not necessarily involve the same mechanisms as sorption.

Effect of age of inoculum on irreversible sorption of Pseudomonas R 3. Sorption of young (log phase) bacteria from ASWG was much faster than that of older bacteria (Fig. I3), but within $24 \mathrm{~h}$. the originally turbid bacterial suspension had completely lysed. Neither growth, lysis, nor sorption were observed with young bacteria in ASWG without $\mathrm{Ca}^{2+}$ and $\mathrm{Mg}^{2+}$.

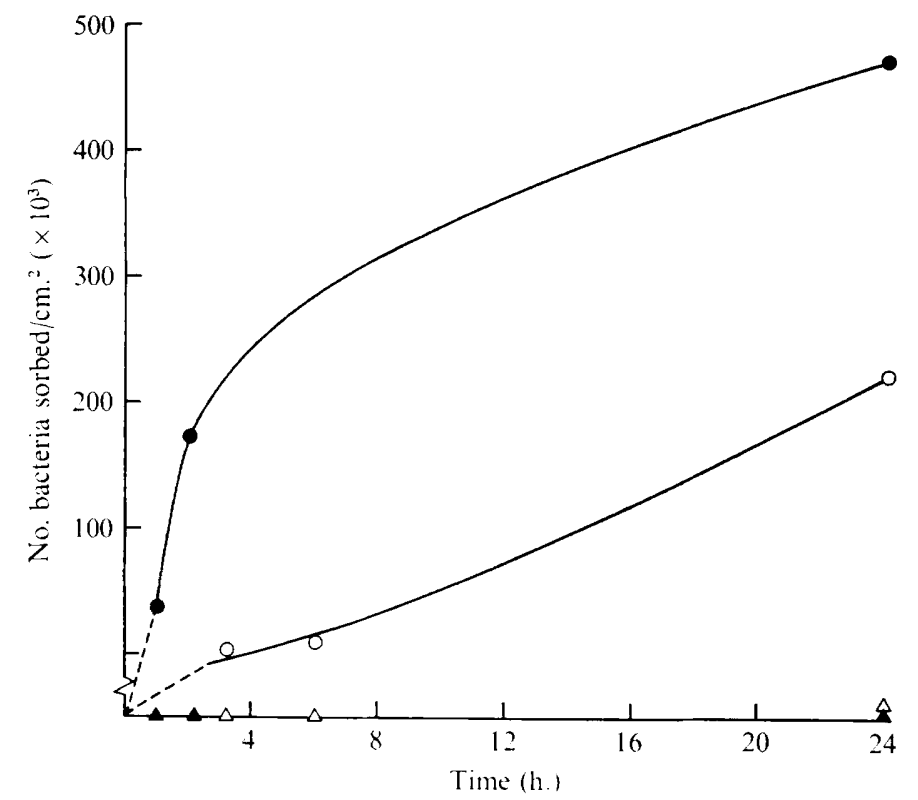

Fig. 13. Effect of age of inoculum on reversible sorption of Pseudomonas R 3 from ASWG. Log phase bacteria in ASWG, all bacteria lysed; $\Delta-\mathbf{\Delta}, \log$ phase bacteria in $\mathrm{ASWG}-\mathrm{Ca}^{2+}$, $-\mathrm{Mg}^{2+}$, no lysis; $O-O$, stationary phase bacteria in ASWG, no lysis; $\triangle-\triangle$, stationary phase bacteria in ASWG $-\mathrm{Ca}^{2+}, \mathrm{Mg}^{2+}$, no lysis.

\section{DISCUSSION}

In the sorption of marine bacteria to surfaces, different mechanisms must be involved in the essentially instantaneous reversible phase and in the time-dependent irreversible phase of sorption.

Reversible sorption. The effects of different concentrations of monovalent and divalent electrolytes on the reversible sorption of Achromobacter $\mathrm{R} 8$ suggest that this phenomenon may be explained in terms of the Derjaguin-Landau and Verwey-Overbeek theory (Shaw, I966; Weiss, 1968). This theory involves an estimation of the magnitude, and variation with interparticle distance, of the London-van der Waals attractive energies between two surfaces and the electrical repulsive energies resulting from the overlapping ionic atmospheres (diffuse double-layers) around the surfaces. 
The energies of interaction between Pseudomonas $\mathrm{R} 3$ and a glass surface at different values for the double-layer thickness have been computed (Weiss \& Harlos, I971) with a programme based on a rearranged version of the formula derived by Hogg, Healy \& Fuerstenau (1966):

where

$$
V_{\mathrm{T}}=V_{\mathrm{R}}+V_{\mathrm{A}},
$$

$$
\begin{gathered}
\left.V_{\mathrm{R}}=\text { repulsion energy }=\frac{\epsilon}{4}\left(\frac{a_{1} a_{2}}{a_{1}+a_{2}}\right)\left[\left(\psi_{1}+\psi_{2}^{\prime}\right)^{2} \ln \left(\mathrm{I}+\mathrm{e}^{-\mathrm{KH}}\right)+\psi_{1}-\xi_{2}\right)^{2} \ln \left(\mathrm{I}-\mathrm{e}^{-\mathrm{KH}}\right)\right], \\
V_{\mathrm{A}}=\text { attraction energy }=-\frac{A}{6} \frac{a_{1} a_{2}}{a_{1}+a_{2}} \frac{\mathrm{I}}{H},
\end{gathered}
$$

where $a$ is the radius of curvature of the particle, $a_{1}=10^{4} \mathrm{~nm}$. (glass) and $a_{2}=0.4 \mu \mathrm{m}$. (bacterium); $\psi$ is the surface potential of the particle, $\psi_{1}=-15 \mathrm{mV}$ (glass), $\psi_{2}=-25 \mathrm{mV}$ (bacterium); $K$ is the inverse Debye-Huckel length, $1 / K$ varies from $0.645 \mathrm{~nm}$. at $2 \times 1 \mathrm{I}^{-1} \mathrm{M}$ $\mathrm{NaCl}$ to $20 \mathrm{~nm}$. at $2 \times 10^{-4} \mathrm{M}-\mathrm{NaCl} ; H$ is the distance of closest approach of the 2 particles; $\epsilon$ is the dielectric constant (of water); $A$ is Hamaker's constant $\left(5 \times 10^{-15} \mathrm{ergs}\right)$.

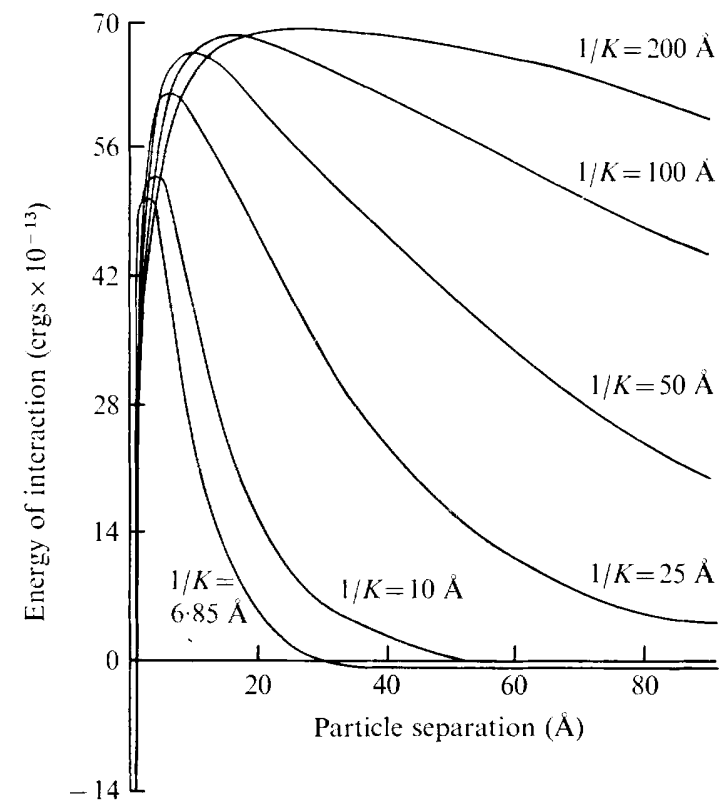

Fig. I4. Computed curves of the energy of interaction between glass and bacterial (Achromobacter $\mathrm{R} 8$ ) surfaces at varying electrolyte concentrations (varying double-layer repulsion) using a value of the Hamaker constant $(A)$ of $5 \times 10^{-15}$ ergs.

The series of curves in Fig. I 4 demonstrate the increase in magnitude of the resultant repulsion curves and the increase in particle separation with decreasing electrolyte concentration (increasing values of $\mathrm{I} / K$ ). At high electrolyte concentrations, a secondary minimum ('attractive trough') is apparent. The progressive increase in repulsion energy with decreasing electrolyte concentration closely parallels the observed decrease in reversible sorption of Achromobacter R 8 (Fig. 3).

In the reversible phase of sorption in seawater or $2.5 \% \mathrm{NaCl}$ it is likely that Pseudomonas $\mathrm{R} 3$ organisms are attracted to the point of the secondary minimum, a small but finite distance from the glass surface. It is unlikely that thermal motion would provide sufficient energy 
for the bacteria to overcome the repulsion barrier. In fact, the kinetic energy of motile Pseudomonas R $3\left(5.45 \times \mathrm{IO}^{-18} \mathrm{ergs}\right)$ is not sufficient to overcome the repulsion barrier at any value for $\mathrm{I} / K$ shown in Fig. I 4 . The magnitude of the attractive energy at the secondary minimum may not be sufficient to hold the bacteria against the shearing effect of the rinsing process. The cine films clearly showed that motile Pseudomonas $\mathrm{R} 3$ could break away from the surface, although the attractive energy held them against violent rotational movements resulting from flagellar activity.

Irreversible sorption. The irreversible phase of sorption implies a firmer adhesion of bacteria to a surface. Polymeric bridging between the bacterial surface and that of the test surface might overcome the repulsion barrier between such surfaces. Such a mechanism has been proposed for the adhesion of tissue cells (Moscona, 1962) and sponge cells (Humphreys, 1965), and for the flocculation of microbial cells (Tenney \& Stumm, I965; Busch \& Stumm, 1968). The electron micrographs presented provide evidence for the production of polymeric fibrils by Pseudomonas $\mathrm{R} 3$. In ASWG without $\mathrm{Ca}^{2+}$ and $\mathrm{Mg}^{2+}$, polymer was not detected and irreversible sorption did not occur. The observation that polymer 'footprints' were left behind when bacteria sheared from the surface suggests that this polymer bound more tightly to the formvar coated surface than to the bacteria.

The fact that extremely low levels of available carbon stimulated irreversible sorption while higher levels inhibited this process may be relevant to microbial ecology. In natural seawaters the available carbon levels are usually very low, and such conditions probably favour the firm adhesion of micro-organisms to surfaces immersed in such environments.

Other factors are probably involved in both phases of sorption of bacteria to surfaces. The sorption to a surface of monolayers of various macromolecules present in seawater or even in bacterial cultures might drastically alter such physical characteristics of the surface as wettability and surface charge properties (Baier, Shafrin \& Zisman, 1968).

This project was supported by a contract no. Nooor4-67-A-0298-0026 from the Office of Naval Research. The authors gratefully acknowledge the help of Dr J. Harlos and Dr L. Weiss (Roswell Park Memorial Institute, Buffalo, N.Y.) for the computations, Dr L. Spielman for helpful suggestions, and Mr G. Pearce for assistance with the electron microscopy.

\section{REFERENCES}

Baier, R. E., Shafrin, E. G. \& Zisman, W. A. (1968). Adhesion: mechanisms that assist or impede it. Science, New York 172, 1360-1368.

Busch, P. L. \& Stumm, W. (I968). Chemical interactions in the aggregation of bacteria bioflocculation in waste treatment. Environmental Science and Technology 2, 49-53.

CORPE, W. A. (1970a). An acid polysaccharide produced by a primary film-forming marine bacterium. Developments in Industrial Microbiology II, 402-412.

CORPE, W. A. (I970b). Attachment of marine bacteria to solid surfaces. In Adhesions in Biological Systems. Edited by R. S. Manly. New York: Academic Press.

Hodgkiss, W. \& Shewan, J. M. (1968). Problems and modern principles in the taxonomy of marine bacteria. In Advances in Microbiology of the Sea, vol. I, I27-166. Edited by M. R. Drood \& E. J. F. Wood. London and New York: Academic Press.

Hogg, R., Healy, T. W. \& Fuerstenau, D. W. (1966). Mutual coagulation of colloidal dispersions. Transactions of the Faraday Society 62, 1938-1951.

Humphreys, T. (1965). Cell surface components participating in aggregation: evidence for a new cell particulate. Experimental Cell Research 40, 539-543.

Marshall, K. C. (197I). Sorptive interactions between soil particles and microorganisms. In Soil Biochemistry, vol. II, ch. I4. Edited by A. D. McLaren and J. J. Skujins. New York: Marcel Dekker.

Moscona, A. A. (1962). Analysis of cell recombinations in experimental synthesis of tissues in vitro. Journal of Cellular and Comparative Physiology 6o, 65-80.

23 
SHAw, D. J. (I966). Introduction to Colloid and Surface Chemistry. London: Butterworth.

Tenney, M. W. \& Stumm, W. (1965). Chemical flocculation of micro-organisms in biological waste treatment. Journal of the Water Pollution Control Federation 37, I370-1 388.

VAITUZIS, A. \& DoETSCH, R. N. (1969). Motility tracks: technique for quantitative study of bacterial movement. Applied Microbiology I7, 584-588.

WeIss, L. (I968). Studies on cellular adhesion in tissue-culture X. An experimental and theoretical approach to interaction forces between cells and glass. Experimental Cell Research 53, 603-618.

Weiss, L. \& Harlos, J. P. (I97I). Short term interactions between cell surfaces. Progress in Surface Science (in the Press).

Wood, E. J. F. (1967). Microbiology of Oceans and Estuaries. Amsterdam: Elsevier.

ZoBELL, C. E. (1943). The effect of solid surfaces upon bacterial activity. Journal of Bacteriology 46, 39-59. 